\title{
The Relationship Between Distinctive Capabilities, Innovativeness, Strategy Types And The Performance Of Small And Medium-Size Enterprises (SMEs) Of Malaysian Manufacturing Sector \\ Mandy Mok Kim Man, Universiti Malaysia Sabah, Malaysia
}

\begin{abstract}
This study was conducted to investigate the relationship between distinctive capabilities, innovativeness, strategy types and the performance of SMEs in the Malaysian manufacturing sectors. The conceptual framework is developed based on the distinctive capabilities, innovativeness, strategy types and the performance. This study is based on a sample survey consisting of 121 SMEs in the manufacturing sector. Using structured questionnaires, the data were collected by mail as well as interviews with owner-managers of the SMEs. The findings indicate that there is no significant relationships between distinctive capabilities, innovativeness and the strategy types on the performance of SMEs.
\end{abstract}

Keywords: distinctive capabilities, innovativeness, strategy types, performance

\section{INTRODUCTION}

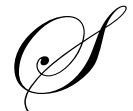

mall and medium- sized enterprises (SMEs) play a significant role in the business system of both developed and developing economics (United Nations, 1993). This study examines the impact of distinctive capabilities, innovativeness and strategy types on the performance of SMEs, and the model builds upon the previous research which suggests distinctive capabilities, innovativeness and strategy types can affect SMEs performance. In the Malaysian context, discussion on small-sized enterprise is always associated with medium-sized enterprises. Like other developing countries, Malaysia is also having difficulties in considering a definition of SMEs. This study defined SMEs as firms that employ less than 200 employees, based on the previous research done by Salleh, M. I. (1990) and Mohd. Asri (1999). This definition is similar to the one used by the World bank (1984), United Nation Development Organisation (1986) and the Asian Development Bank (1990) who defined small enterprises as firms employing fewer than 50 employees and medium enterprises as firms employing between 50 to 199 employees.

\section{LITERATURE REVIEW}

\section{The Distinctive Capabilities}

The literature on strategic management suggests distinctive capabilities or competencies as an important part of an organization's resources and competitive advantage. Mintzberg and Quinn (1991) noted that theoretical relevance of distinctive capabilities as source of competitive advantage can be traced back to the early work by Selznick (1957). 
Graig and Grant, (1993) defined a firm's distinctive capabilities or competencies as both tangible and intangible resources, comprising of financial, physical, human, technology, reputation and relationship which a firm owns or has access too.

Aaker (1989) noted that the assets and skills of the firm, which are the basis for competition, provide the foundation for sustainable competitive advantage. Furthermore, Aaker pointed that it is the essence of strategic management to develop and maintain these assets and skills as well as to choose these strategies so that they can be turned into sustainable competitive advantages.

Identifying and classifying resources or assets in a firm is a difficult task (Graig and Grant, 1993). However, basically, resources can be grouped into tangible and intangible assets. Ansoff, (1965), Wheellen and Hunger (1995), and Price (1996) classified business functional areas into general administration, operations/ production, marketing, finance, human resource management, engineering and $\mathrm{R} \& \mathrm{D}$ and public relations. Hitt and Ireland (1985) developed distinctive capabilities instrument comprising 55 capabilities grouped according to seven functional areas; a) general administration, b) production/operations, c) engineering, research and development, d) marketing, e) finance, f) personnel, and g) public and governmental relations. The distinctive capabilities variables used in this study are adopted from this literature review.

\section{Innovativeness}

Innovativeness is defined by Urabe (1988) as "the generation of a new idea and its implementation into a new product, process, or service, leading to the dynamic growth of the national economy and the increase of employment as well as to a creation of pure profit for the innovative business enterprise". Further, Albach (1988) indicated that development of a new idea into a product, process, or service can increase a firm's market share, and leads to a better firm's performance. Firms which effectively implement innovativeness can enjoy several possible profits. Firms can benefit from increased productivity and adaptability owing to process improvements (Sankar, 1991, Burgelman and et al., 1988). In addition, implementation of new ideas can increase company productivity and efficiency, lead to higher firm's performance (Edosomwan, 1989). Study of Edosomwan, 1989 also showed that effectively using organization's new ideas will create an environment condusive to innovativeness. The developments can then create new opportunities for the firm and provides firms with competitiveness advantages (Abernathy and et al., 1988).

In simple terms, innovativeness involves the commercial exploitation of new ideas. As Freeman (1982) indicated that innovativeness is the first commercial transaction involving the new product, process, system or device.

In the study by Damanpour (1987), specialization and organizational slack had strong effects on technical innovation. The importance of innovativeness has been acknowledge conceptually but rarely examined empirically. There is empirical support for positive relationship between competitive intensity and innovativeness (Zajac, Golden and Shortell, 1991). According to Damanpour (1987), innovativeness can take place in shorten the manufacturing cycle time and lowering the cost, and also by changing the product design, product variety and management process by restructuring the organization. This study adopted Damanpour model in measuring the innovativeness of the SMEs. However, the recent study done by Lin and Chen (2007) on Taiwan SMEs shows that $80 \%$ of the surveyed firms applied technological innovation in the firms, and the technological innovation factor did not explaining the sales.

\section{Strategy}

The word strategy is derived from the Greek word "strategos," which means army and leading. Initially, the concept of strategy was referred to the leading role of a general in command of an army as well as meant for military purposes (Greenly, 1989; and Mintzberg and Quinn, 1991).

According to Wren (1994), the earlier concept of strategy used in military organizations was meant for the purpose of deciding the decision rules based on the evaluation of the enemy's strengths. 
Further, Quinn (1980) indicated that the concept of strategy in military organizations was used for various military purposes such as developing organizational objectives, maintaining the initiative, concentrating organizational resources, conceding selected positions, flexibility, and coordinating and commitment. Likewise, initially, the adoption of the original concept of strategy in the context of business organizations was also meant for these same purposes.

Strategy is defined as a major action taken or planned by the management of a business organization, considering its resources, skills and environment risks. Corporate strategy usually refers to the product- market choices of the firms (Hofer and Schendel, 1978).

Strategic management is important to an organisations (David, 1999, Wheelen and Hunger, 1995). Firms use business strategy to outline the fundamental steps that they plan to follow in order to accomplish their objectives. Glueck and Jauch (1984) grouped the objectives to be achieved by organisations as to achieve long range objectives such as to generate profits, improve marketing and sales, objectives related to the workforce such as efficiency, motivation, as well as improving corporate responsibility.

Diversification refers to the act of extending the number of product lines or entering into a variety of industries. Vertical integration is used to mean the act of attempting to control material resources (back- ward integration) or to control the channel of distribution (forward integration).

There are three different levels of corporate level strategy, business level strategy and functional level strategy, the theoretical and empirical studies of the relationship between strategy and organisational performance have mainly emphasised on business level strategy (Lee, 1987).

Porter (1980) noted that a firm can gain its competitive advantage by producing value for its customers. Porter also stressed that a firm can gain its competitive advantage by performing the chain of strategically important activities (such as production, marketing, sales, service, human resource management, technology development, procurement activities) cheaply or better than its competitors. Further, Porter concluded that strategic types based on these activities are known as generic strategies. According to Porter, the three generic strategies are low cost, differentiation and focus. This study adopts Porter's three generic strategies (low cost, differentiation, focus) for the research. Since this study chose SMEs as the sample, "focus strategy" is adopted as "niche strategy" to suit to the sample of this study.

\section{The Performance}

The primary goal of adopting effective management process is improved organisational performance. As such, some methods of measuring organisational performance is needed to determine how well an organisation is functioning as a result of adopting the strategic management process.

Organisational performance can be measured by many criterias. In general, the literature suggests that organisational performance is commonly measured in terms of effectiveness, efficiency, growth and productivity.

However, according to Robinson (1982); Montanari, Morgan and Bracker (1990), firms tend to focus on effectiveness when measuring their organisational performance.

Montanari, Morgan and Bracker (1990) suggested that organisational effectiveness may be measured in terms of financial measures, operational measures as well as behavioural measures. First, the authors noted that the financial measures such as profitability and growth can be used to access the financial performance of an organisation. Second, the operational measures such as productivity, resource acquisition, efficiency and employee reaction can be adopted to assess the effectiveness of the work flow as well as work support in organisations. Third, behavioural effectiveness measures such as adaptability, satisfaction, absence of strain, development and open communication can be adopted to determine individual performance.

Goodman and Pennings (1997) pointed that there is still disagreement on the meaning of organisational effectiveness. According to the authors, in addition to various definitions by different authors, there is also the 
tendency among authors to view effectiveness as either one-dimensional or multidimensional.

Goodman and Pennings further claimed that the underlying differences in conceptualising organisational effectiveness resulted from the different views concerning the nature of organisations. According to the authors, the different views concerning the nature of organisations have implicitly or explicitly determined the conceptual definition of organisational effectiveness. The first view sees an organisation as a rational set of arrangements and emphasised toward achieving certain goals defined effectiveness in terms of the goals attainment. Second, the opensystem perspective of organisations defined effectiveness as the degree to which an organisation can maintain all its components.

The process of determining the performance of an organisation requires the selection and the measuring of a set of key variables that can allow the organisation to detect as well as monitor its competitive position in the business it engages. In another words, measuring performance is also one of the important steps in the strategic control process (Griffith, 1987; and Wheelen and Hunger, 1995).

Lee (1987) claimed that a commonly accepted overall criterion of business performance has yet to be developed. The author stressed that it is not easy to established the appropriate standard to evaluate performance since different business may have organization objective. Lee pointed that in general, previous literature on strategic management has recognized financial profitability as the most accepted measure of business performance. This study measures the firms' performance in term of business performance composite index (BPCI). Sales, assets, net profit, equity, return on sales (ROS), return on investment (ROI), return on asset (ROA) are used to assess the SMEs performance. The BPCI is developed from the mean values of ROS, ROI and ROA [BPCI $=(\mathrm{ROS}+\mathrm{ROI}+\mathrm{ROA}) / 3]$. This study adopted Lee (1987) model on measurement of the SMEs' performance.

\section{Relationship between Distinctive Capabilities, Innovativeness, Strategy and Performance}

The ability of an organisation to survive and succeed is influenced by various factors, some of which can and some which can't be controlled. Therefore the performance of an organisation is a function of the controllable and uncontrollable variables (Kim and Lim, 1988).

In this study, the distinctive capabilities variable was based on the seven general functional areas found in most manufacturing firms. The distinctive capabilities variable was measured by using the instrument developed by Hitt and Ireland (1985).

This study adopts Damanpour (1987)'s study as the measures of firms's innovativeness performance. The innovativeness in this study is measured from the aspects of lowering costs, changing product design, manufacturing cycle time, product variety and organization restructuring. The distinction between organization and innovativeness is important because it relates to a more general distinction performance and technology (Evan, 1966). Administrative and innovations imply potentially different decision- making processes (Draft, 1978) and together they represent changes introduced in a wide range of activities in an organization. This innovation dichotomy has been shown to relate differently to the same predictor variables (Kimberly and Evanisko, 1981, Damanpour, 1987; Han et al., 1998). According to Damanpour (1991), organizational performance depends more on innovations of different types than each type alone. Further to that, innovation of different type influence and often complement each other (Han et al., 1998). Innovativeness is more effective in helping organizations to maintain or improve their level of performance (Damanpour and Evan, 1984).

Many studies of organizational innovation have measured innovation by the number of innovations adopted in given time period. When multiple innovations are studied, the influence of innovation attributes decreases. Differentiating studies on the basis of scope of innovations studied should provide useful information for explaining the instability of empirical research findings.

For technical innovativeness, it covers new product, improvement in current product whether in terms of performance or aesthetic, implementation of new automation, new equipment, new processes or technique of operation for shorter cycle time, design for manufacturability and finally improvement in the raw materials or 
supply.

Management chooses and implements competitive strategies to face the fast and dynamic changes in the environment. Since strategy is meant for competing with other organisations, the results of strategy implementation can be seen from the performance achieved by the organisation (Beard \& Dess, 1981; Parnell \& Wright, 1993).

The strategies developed by organisations can be influenced by how management perceives the environment faced by them (Daft, Sormunen \& Parks, 1988). Even though firms face the same environment, they might choose different strategies (Thomas, Litschert \& Ramasamy, 1991).

Organisations in a turbulent environment are likely to choose a differentiation strategy compared to organisations operating in a stable environment (Marlin et al., 1994). In their analysis, Kim and Lim (1988) found that high performance organisations adopting the cost leadership and differentiation strategy operate in different environments. In addition, Parnell and Wright (1993) stressed that organisations implementing the prospector strategy or differentiation strategy enjoy high-income growth as compared to organisations implementing cost leadership and focus strategy. In assisting the foreign manufacturing firms in Malaysia to cope with the new challenges, the Malaysia government has already began accelerating the operation of the manufacturing firms through various steps such as focusing on quality, encouraging more high technology ventures, introducing further tax cuts, developing efficient operations and upgrading the standards of health and safety. These will influence the strategy practices and performance of the foreign manufacturing firms in Malaysia. Furthermore, the Malaysia government will continue to transform the manufacturing industry into a more dynamic sector with high value added, capital intensive, high technology as well as skill and knowledge intensive manufacturing industry.

\section{THE RESEARCH FRAMEWORK}

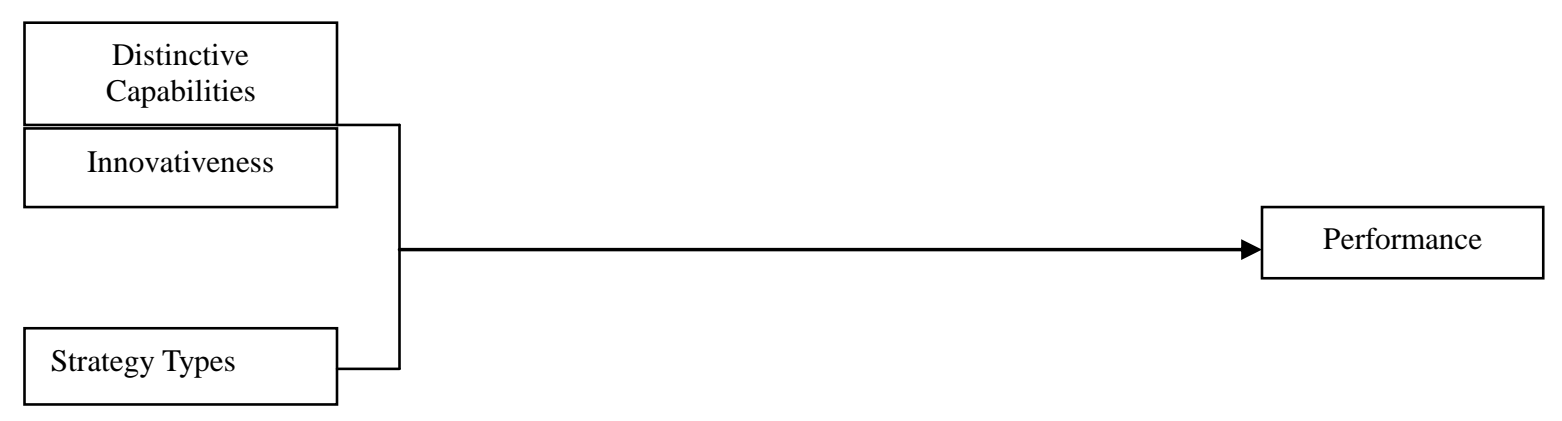

\section{RESEARCH METHODOLOGY}

The SMEs registered in the Ministry of International Trade and Industry (MITI) and Malaysian Industrial Development Authority (MIDA) were used as the sampling frame in the study. The organisations selected from the list are those that are involved in manufacturing activities and have been listed for at least five years. Mailed questionnaires were used to collect the data required for the study, at the same time, interview with the Chief Executive Officer (CEO) of certain SMEs was conducted for those SMEs which did not return the questionnaires. The questionnaires were sent to the chief executive officer of each firm requesting them to respond to the questionnaire.

The 50 distinctive capabilities developed by Hitt and Ireland (1985), which grouped into seven functions, were tested in the questionnaires. The seven functions in this study were measured in terms of their levels (degree) in the firms. The levels of the distinctive capabilities were determined by requesting the owners/manager to rate each capability on a five-point numerical scale ranging from "none" to "very high".

This study adopts lowering costs, changing product design, manufacturing cycle time, product variety and organization restructuring as the measures of SMEs innovativeness, which grouped into four functions, were tested in the questionnaires. The four functions in this study were measured in terms of their levels (degree) in the firms. 
The levels of the innovativeness were determined by requesting the owners/manager to rate each level of innovativeness on a five-point numerical scale ranging from "very low" to "very high".

This study adopts low cost strategy, differentiation strategy and niche strategy as the measures of SMEs' strategy types, which grouped into three groups, were tested in the questionnaires. The three types of strategies in this study were measured in terms of their rating in the firms. The rating of the strategy types were determined by requesting the owners/manager to rate each strategy types on a five-point numerical scale ranging from "least applicable" to "most applicable".

The previous research reviews suggest that it is not possible to choose a single performance measures that is equally appropriate for all business firms. Based on the literature, this study concludes that in order to describe SMEs performance more fully, combination or multiple measures are needed so that they are able to provide more definitive answer on how efficiently and effectively SMEs is being managed.

In this study, performance is the dependent variable that is presented in the theoretical framework. This study measures business composite performance index (BPCI) as the performance measures as in Lee (1987)'s study. Data for this measure was collected for the years 1999 to 2003.

\section{Statistical Methods Used}

This study used various statistical methods to test the hypotheses of the research model. The hypotheses were tested using the multiple regression analysis. The first part of the analysis is concerned with the descriptive statistics of each of the item under each main variable. The multiple regression is used to test hypothesis 1,2 and 3. The multiple regression is used to test the significant mean differences between the performance measures and the distinctive capabilities, innovativeness and strategy types variables.

\section{Hypotheses}

Three hypotheses were tested for this study. They are:

1. There is a significant relationship between distinctive capabilities and the performance of SMEs.

2. There is a significant relationship between innovativeness and the performance of SMEs.

3. There is a significant relationship between strategy types and the performance of SMEs.

\section{RESULTS}

This study managed to cover 26 of the 35 manufacturing industries identified by the Ministry of International Trade and Industry (MITI). Of the 121 firms in the 26 different industries surveyed, 17 firms (14.0\%) were in the food industry, eight firms $(6.6 \%)$ in the beverage industry, two firms $(1.7 \%)$ in the agricultural industry, 10 firms (8.3\%) in the building material and related industry, three firms (2.5\%) in the stationery industry, six firms $(5.0 \%)$ in the packaging, labelling and printing industry, two firms $(1.7 \%)$ in ceramics and tiles industry, one firm $(0.8 \%)$ in tobacco industry, 10 firms $(8.3 \%)$ in textile products industry, one firm $(0.8 \%)$ in wood products industry, six firms $(5.0 \%)$ in the furniture industry, four firms $(3.3 \%)$ in the paper products industry, three firms $(2.5 \%)$ in the chemical industry, and pharmaceutical industry, two firms (1.7\%) in rubber products industry, four firms (3.3\%) in plastic products industry, one firm $(0.8 \%)$ in non-metallic industry, 15 firms $(12.4 \%)$ in electrical and electronics industry, eight firms (6.6\%) in supporting products industry, two firms (1.7\%) in souvenir and handicrafts industry, one firm $(0.8 \%)$ in sports goods and equipment industry, one firm $(0.8 \%)$ in jewellery and related products industry, two firms (1.7\%) in motor vehicle components industry, six firms $(5.0 \%)$ in household appliances industry, one firm $(0.8 \%)$ in laboratory equipment industry, and two firms $(1.7 \%)$ in miscellaneous industries. Table 1 presents the summary of the firms by type of industry. 
Table 1: The Sample Firms By Type Of Industry

\begin{tabular}{|c|c|}
\hline Type Of Industry & Frequency $/(\%)$ \\
\hline 1. Food & $17(14.0)$ \\
\hline 2. Beverage & $8(6.6)$ \\
\hline 3. Agricultural products & $2(1.7)$ \\
\hline 4. Building material \& related products & $10(8.3)$ \\
\hline 5. Stationery & $3(2.5)$ \\
\hline 6. Packaging, labeling \& printing & $6(5.0)$ \\
\hline 7. Ceramics \& tiles & $2(1.7)$ \\
\hline 8. Tobacco & $1(0.8)$ \\
\hline 9. Textile products & $10(8.3)$ \\
\hline 10. Wood products & $1(0.8)$ \\
\hline 11. Furniture \& fixtures & $6(5.0)$ \\
\hline 12. Paper Products & $4(3.3)$ \\
\hline 13. Industrial chemical & $3(2.5)$ \\
\hline 14. Pharmaceutical products & $3(2.5)$ \\
\hline 15. Rubber products & $2(1.7)$ \\
\hline 16. Plastic products & $4(3.3)$ \\
\hline 17. Non-metallic products & $1(0.8)$ \\
\hline 18. Electrical, electronics products & $15(12.4)$ \\
\hline 19. Supporting products & $8(6.6)$ \\
\hline 20. Souvenirs \& handicrafts & $2(1.7)$ \\
\hline 21. Sports goods \& equipment & $1(0.8)$ \\
\hline 22. Jewellery \& related products & $1(0.8)$ \\
\hline 23. Motor vehicles components & $2(1.7)$ \\
\hline 24. Household appliances & $6(5.0)$ \\
\hline 25. Laboratory equipment & $1(0.8)$ \\
\hline 26. Miscellaneous & $2(1.7)$ \\
\hline Total & 121 \\
\hline
\end{tabular}

The descriptive statistic output for the firm characteristics is presented by Table 2.

Table 2: Firm Characteristics

\begin{tabular}{|l|c|}
\hline \multicolumn{1}{|c|}{ Firm Characteristics } & Frequency /(\%) \\
\hline Founder & $23(19.0)$ \\
\hline Cofounder & $12(9.0)$ \\
\hline Inherited from family & $7(5.8)$ \\
\hline Purchased business not from family & $11(9.1)$ \\
\hline Hired or promoted by the company & $68(56.2)$ \\
\hline Total & 121 \\
\hline
\end{tabular}

As shown by Table 2, most of the respondents, $68(56.2 \%)$ of them hired or promoted by the company. 23 $(19.0 \%)$ of the respondents are the founder and $12(9.0 \%)$ of them are the cofounder. $11(9.1 \%)$ of the respondents purchased the business not from family and seven $(5.8 \%)$ of them inherited or purchased the business from the family.

A multiple regression analysis was adopted to examine the significant relationship between distinctive capabilities and the performance of SMEs. Table 3 presents the results for multiple regressions for distinctive capabilities, innovativeness and strategy types variables on the performance of SMEs. 
Table 3: Regression Analyses Result between the Distinctive Capabilities, Innovativeness and Strategy Types toward the Performance of SMEs

\begin{tabular}{|c|c|c|c|c|c|}
\hline $\begin{array}{c}\text { Independent } \\
\text { Variable }\end{array}$ & $\begin{array}{c}\mathbf{R} \text { square } \\
\left(\mathbf{R}^{2}\right)\end{array}$ & $\begin{array}{c}\text { Sig. } \\
\text { F value }\end{array}$ & $\begin{array}{c}\text { Beta } \\
\text { Coefficients }\end{array}$ & t-value & $\begin{array}{c}\text { Durbin- } \\
\text { watson }\end{array}$ \\
\hline Distinctive capabilities & 0.061 & 0.398 & 0.292 & 1.365 & 1.838 \\
\hline \multicolumn{6}{|c|}{ Dependent Variable: Performance } \\
\hline $\begin{array}{c}\begin{array}{c}\text { Independent } \\
\text { Variable }\end{array} \\
\end{array}$ & $\begin{array}{c}\mathbf{R} \text { square } \\
\left(\mathbf{R}^{2}\right)\end{array}$ & $\begin{array}{c}\text { Sig. } \\
\text { F value }\end{array}$ & $\begin{array}{c}\text { Beta } \\
\text { Coefficients } \\
\end{array}$ & t-value & $\begin{array}{r}\text { Durbin- } \\
\text { watson }\end{array}$ \\
\hline Innovativeness & 0.077 & 0.233 & 0.294 & 1.313 & 1.889 \\
\hline \multicolumn{6}{|c|}{ Dependent Variable: Performance } \\
\hline $\begin{array}{c}\begin{array}{c}\text { Independent } \\
\text { Variable }\end{array} \\
\end{array}$ & $\begin{array}{c}\text { R square } \\
\left(\mathbf{R}^{2}\right)\end{array}$ & $\begin{array}{c}\text { Sig. } \\
\text { F value }\end{array}$ & $\begin{array}{c}\text { Beta } \\
\text { Coefficients }\end{array}$ & t-value & $\begin{array}{c}\text { Durbin- } \\
\text { watson }\end{array}$ \\
\hline Strategy Types & 0.006 & 0.885 & 0.116 & 0.801 & 1.865 \\
\hline
\end{tabular}

** significant at 0.01 level (2-tailed)

*significant at 0.05 level (2-tailed)

The results of the regression analyses in Table 3 indicated that distinctive capabilities, innovativeness and strategy types did not contribute significantly to the performance of SMEs. By looking at the regression results, distinctive capabilities explains 6.1\% (R-square= 0.061) of the variation in SMEs' performance. The relationship between the distinctive capabilities and performance is not significant $(\mathrm{p}=0.398>0.005)$. The relationship between the innovativeness and performance is also not significant $(\mathrm{p}=0.233>0.005)$. The innovativeness explains $7.7 \%(\mathrm{R}-$ square $=0.077$ ) of the variation of the performance of SMEs. For the relationship between the strategy types and the performance, the results also show that there is no significant relationship $(\mathrm{p}=0.885>0.005)$. The strategy types explains $0.6 \%(\mathrm{R}$-square $=0.006)$ of the variation of the performance. Generally, the results of the regression analyses for the variables tested in this study have low R-square. The previous studies on Malaysia SMEs done by Hashim (2000) with 100 respondents and Tarsiah (2007) with 84 respondents also show the low R-square, within range 0.1 to 0.9 . The low R-square may be contributed by the limited sample size. Owing to the time constraints, the respondents for this study is limited to 121 respondents. This is the limitation for this study. Since the Durbinwatson values range from 1.838 to 1.889 , and they are close to 2 , their successive residuals are not correlated and so they are considered as a good data.

\section{DISCUSSION AND CONCLUSION}

This study focuses on SMEs from the perspective of strategic management. The study attempted to examine the influence of strategic management variables on the performances of SMEs. More specifically, the primary objective of the study was to examine empirically the influence of distinctive capabilities, innovativeness and the strategy types on the performance of SMEs in the Malaysian manufacturing sector.

Table 4: Summary of Overall Results

\begin{tabular}{|c|l|c|c|}
\hline No. & \multicolumn{1}{|c|}{ Hypothesis } & Statistical Test & Result \\
\hline 1. & $\begin{array}{l}\text { Hypothesis 1: There is a significant relationship between } \\
\text { distinctive capabilities and the performance of SMEs. }\end{array}$ & Multiple Regression & Rejected \\
\hline 2. & $\begin{array}{l}\text { Hypothesis 2: There is a significant relationship between } \\
\text { innovativeness and the performance of SMEs. }\end{array}$ & Multiple Regression & Rejected \\
\hline 3. & $\begin{array}{l}\text { Hypothesis 3: There is a significant relationship between the } \\
\text { strategy types and the performance of SMEs. }\end{array}$ & Multiple Regression & Rejected \\
\hline
\end{tabular}

As shown in Table 3, Hypothesis 1 states that there is a significant relationship between distinctive capabilities and the performance of SMEs is rejected. These findings appear not consistent with the study conducted by Stoner (1987). According to Stoner, most small firms recognised the need for building and developing distinctive 
capabilities as a competitive strategy. Besides Stoner (1987)' study, there are many previous researchers on distinctive capabilities. Hubbard et al. (1997) indicated that distinctive capabilities is a skill that an organization possesses that enables it to perform activities. According to Javidan (1998), the distinctive capabilities will influence the core competencies of the organization. Further, Ghosh et al. (2001) found that the key success factors and distinctive capabilities contributed to the performance of SMEs. Ghosh et al. (2001) measured distinctive capabilities from the aspects of management team, leaderships, correct strategic approach, marketing, develop and sustain capability and good customer and client relationship.

Although the study by Hitt and Ireland (1985) indicated that distinctive capabilities variables does influence the performance of the firm, this study does not congruent with the Hitt and Ireland (1985)'s study. This might be contributed by the Hitt and Ireland (1985)'s instrument which is developed in United States of America to measure distinctive capabilities of SMEs in Malaysia. Owing to the different environment in United States of America and Malaysia, it gives the different findings. Therefore, it is recommended that more comprehensive studies are to be conducted on this distinctive capabilities variable to identify the reasons behind the contradictory findings.

The findings of this study appear not to concur with the study conducted by Abbey and Dickson (1983). Abbey and Dickson (1983) concluded that the climate of innovate R\&D units is characterized by rewards given in recognition of excellent of performance and this performance will indirectly influence the performance of the organization. Damanpour (1987) indicates that the importance of innovativeness in the firm has been rarely examined empirically. According to Damanpour and Evan (1984), innovativeness is more effective in helping organizations to maintain or improve their level of performance.

However, despites the above studies, as reported earlier, the recent study done by Lin and Chen (2007) shows that $80 \%$ of the surveyed firms applied technological innovation in the firms, and the technological innovation variable does not explaining the firms' performance. Therefore, it is recommended that further studies to give a broader view on this innovativeness variable.

As shown by Table 3, the findings appear incongruent with Porter's (1980) study of the three generic strategy types (low cost, differentiation, and focus). Porter noted that the ability of firms to survive will depend upon their ability to adopt strategy types that can differentiate them from their competitors. Novel conclusions have emerged from the present study, that are different from previous researches. It has been concluded from previous studies that there is a significant relationship between the strategy types and the firms' performance, as highlighted in the study of Porter (1987). In contrast to earlier investigations, it was found in the present study that there was no significant relationship between the strategy types and the SMEs' performance. In the last 20 years or so, aspects of the performance of firms may have changed considerably. As a consequence, the distinctive capabilities may no longer relate significantly to the performance of SMEs. The recent research by Lin and Chen (2007) found no significant relationship between innovativeness and firms' performance. Clear evidence for the operation of a time change factor is supported from the very different nature of the conclusions that were drawn from this latter study. Clearly, changes in the distinctive capabilities, innovativeness and strategy of SMEs with the passage of time provide an opportunity to undertake further research in this area, to clarify the dynamics of the change process.

\section{Limitation of the Study}

The nature of the research questions of this study required extensive contact with as many owner/managers in a limited environmental setting. Getting the SMEs to participate in the research was the major problem that this study faced. When approached, many of them refused to participate. This problem and other issues have contributed to the limitations of the study. The limitation of the study was related to the number of SMEs in the manufacturing sector which could be selected for this study. The number of firms surveyed in the study may be small. However, this might be overcome in the future if more SMEs could be encouraged to participate, and that the research should expand to include not only SMEs in Malaysia, but also in the others countries. 


\section{Contribution of the Study}

This research suggests more comprehensive studies are to be conducted by researchers in exploring the relationship between the distinctive capabilities, innovativeness and strategy types and the performances of SMEs. More empirical research is needed and will be particularly useful in providing more empirical evidence to identify the reasons behind the contradictory findings. There is a need then to conduct studies on SMEs in the other different sectors such as wholesaling, retailing, and construction in order to develop a more comprehensive theory and understanding of SMEs. This is particularly important in the Malaysian context, where very few studies have focused on examining SMEs in sectors other than the manufacturing.

\section{AUTHOR INFORMATION}

Ms. Mandy Mok Kim Man obtained her Bsc, (Hons) International Business in Universiti Malaysia Sabah, Msc (Human Resource Management And Development) in Universiti Teknologi Malaysia and now waiting for VIVA for her PhD (Strategy Management) in Universiti Malaysia Sabah, Malaysia. She was awarded for the Praised Lecturer of Universiti Malaysia Sabah in year 2006, year 2007 and year 2008. She is also very active in consultancy and research work. Her field of interests are international business, human resource management and development, strategy management, cross culture study, marketing, organizational learning and etc.

\section{REFERENCES}

1. Aaker, David A. (1989). Managing Assets and Skills: The Key to a Sustainable Competitive Advantage. California Management Review, Winter: 91-106.

2. Abbey, Augustus and Dickson, John W. (1983). R\&D Work Climate and Innovation in Semiconductors, Academy of Management Journal, 26: 362-368.

3. Abernathy, W.J. and Clark, K.B. (1988). Innovation: Mapping The Winds of Creative Destruction. Readings in the Management of Innovation, $2^{\text {nd }}$ ed., Harper Business, New York.

4. Ansoff, H. Igor (1965). Corporate Strategy, New York: John Wiley \& Sons.

5. Asian Development Bank (1990). Malaysia: Study on Small and Medium Enterprises with Special Refences to Technology Development, Staff Working Paper, April.

6. Beard, D. W. and Dess, G. (1981). "Corporate Strategy, Business Level Strategy and Firm Performance". Academy of Management Journal. Vol. 20, 663-688.

7. Burgelman, R.A. and Maidique, M.A. (1988). Strategic Management of Technology and Innovation, Irwan, Homewood, IL.

8. Buzzel, R., Gale, B. \& Sultan, R. M. (1975). "Market share: A Key to Profitability". Harvard Business Review. Vol. 53, 97-106.

9. Daft, R.L. (1978). A Dual Core Model of Organizational Innovation, Academy of Management Journal, 21:193-210.

10. Daft, R.L., Sormunen, J. \& Parks, D. (1988). "Chief Executive Scanning, Environmental Characteristics, and Company Performance: An Empirical Study". Strategic Management Journal. Vol. 9, 123-139.

11. Damanpour, F. (1987). The Adoption of Technological, Administrative and Ancillary Innovations: Impact of Organizational Factors, Journal of Management, 13: 675-688.

12. Damanpour, F. (1991). Organizational Innovation: A Meta- analysis of Effects of Determinants and Moderators, Academy of Management Journal, 34: 555-590.

13. Damanpour, F. and Evan, W.M. (1984). Organizational Innovation and Performance: the Problem of Organizational Lag., Admin. Science Quarterly, 29: 392-409.

14. Edosomwan, J.A. (1989). Integrating Innovation and Technology Management. Wiley-Interscience, New York.

15. Evan, W.M. (1966). Organizational Lag, Human Organizations, 25, Spring, 51-53 in Damanpour (1991).

16. Freeman, C. (1982). The Economics of Industrial Innovation, Frances Pinter, London.

17. Galbraith, Craig and Schendel, Dan. (1983). An Empirical Analysis of Strategy Types. Strategic Management Journal. Vol.4: 153-173. 
18. Ghosh, B.C., Tan W.L., Tan T.M. and Chan Ben. (1991). An Exploratory Study of Strategic Planning Behaviour in SMEs in Singapore/Malaysia Context. Proceedings of the World Conference on

Entrepreneurship and Innovative Change. Nanyang Technological University, Singapore, July 3-5.

19. Glueck, W.F and Jauch, L.R. (1984). Business Policy and Strategic Management. New York: Mc. Graw Hill.

20. Goodman, Paul S. and Pennings, Johannes M. (1997). New Pesrspective on Organisational Effectiveness. San Francisco: Jossey-Bass Publisher.

21. Greenly, Gordon E. (1989). Strategic Management, London: Prentice Hall International.

22. Griffin, Ricky W. (1987). Management. $2^{\text {nd }}$ edn. Boston: Houghton Mifflin.

23. Han, Jin K., Kim, Nam Woon and Srivastava, Rajendra K. (1998). Market Orientation and organizational Performance: Is Innovation a Missing Link?, Journal of Marketing, 62, Oct, 30-45.

24. Hashim M.K. et al.. (2001a). Testing Environment as the Moderator between Competitve Strategy and Performance Relationship: A Case of Malaysian SMEs. Proceedings of the $46^{\text {th }}$. ICSB World Conference, Taiwan.

25. Hashim M.K. et al.. (2001b). "Firm Characteristics, Competitive Strategy, Environment, and Business Performance: Survey Evidence from Malaysian SMEs". Journal ANALISIS. June.

26. Hayes, R.H., Wheelwright, S.C. and Clark, K.B. (1988). Dynamic Manufacturing: Creating the Learning Organization, The Free Press, New York. NY.

27. Hitt, Michael A. and Ireland, R. Duanne. (1985). Corporate Distinctive Competence, Strategy, Industry and Performance. Strategic Management Journal. Vol. 6: 273-293.

28. Hitt, Michael A. and Ireland, R. Duanne. (1986). Relationships Among Corporate Competencies, Diversification Strategy, Corporate Structure and Performance. Journal of Management Studies. July: 401416.

29. Hofer, C.W. and D.E. Schendel (1978). Strategy Formulation: Analytical Concepts, St. Paul: West Publishing.

30. Hubbard, G.., Pocknee, G.. and Taylor, G.A..(1997). Practical Australian Strategy, Prentice-Hall, Sydney.

31. Javidan, Mansour, (1998). Core Competence: What Does It Mean In Practice? Long Range Planning. 31(1):60-71.

32. Kim, L., and Y. Lim. (1988). "Environment, Generic Strategies and Performance in a Rapidly Developing Countries: A taxonomic Approach". Academy of Management Journal. Vol. 31, pp. 802-827

33. Kim, Youngbae and Choi, Youngrok. (1994). Strategic Types and Performance of Small Firms in Korea. International Small Business Journal. Vol.13,No.1: 13-23.

34. Kimberly, J.R. and Evanisko, M.J. (1981). Organizational Innovation: The Influence of Individual, Organizational and Contextual Factors in Hospital Adoption of Technological and Administrative Innovations, Academy of Management Journal, 24: 698- 713.

35. Kotha, S and Nair A. (1995). Strategy and Environment as Determinants of Performance: Evidence from the Japanese Machine Tool Industry. Strategic Management Journal. Vol.16, No.7: 497-518.

36. Lamb, Hair \& Mc. Daniel. (1996). "Marketing," $3^{\text {rd }}$. Ed. New York: South-Western.

37. Lee, Jooh. (1987). A Comparative Study of the Relationship Between Strategy and

38. Business Performance: Industrialised Countries and Newly-Industrialising Countries. Published PhD Dissertation. University of Mississippi.

39. Li, Mingfang, and Simerly, Roy L. (1998). The Moderating Effect of Environmental Dynamism on the Ownership and Performance Relationship. Strategic Management Journal. Vol. 19: 169-179.

40. Lin, Carol Yeh-Yun and Chen Mavis Yi-Chung (2007). Does Innovation Lead To Performance? An Empirical Study of SMEs in Taiwan, Journal of Management Research News, 30 (2).

41. Manu, Franklyn A. and Sriram, Ven. (1996). Innovation, Marketing Strategy, Environment, and Performance. Journal of Business Research. Vol.35:79-91.

42. Marlin, D, Hoffman, J. and Lamont, B. T. (1994). "Porter's Generic Strategies, dynamic Environments, and performance: A Profile Deviation Fit Perspective". International Journal of Organizational Analysis. Vol. 2, No. 2 (April), 155-175.

43. Miles, J., Coven, J. \& Heeley, M. (2000). "The Relationship between Environmental Dynamism and Small Firms, Structure and Performance". Journal of Marketing Theory and Practice. Spring, 8, 2, 63-78.

44. Miller, D. (1988). "Relating Porter's Business Strategies to Environment and Structure: Analysis and Performance Implications”. Academy of Management Journal. Vol. 31,No. 2, 280-308. 
45. Ministry of Finance Malaysia (2001). Economics Report 2001/2002, Kuala Lumpur: PNMB.

46. Mintzberg, Henry and Quinn, James Brian (1991). The Strategy Process, $2^{\text {nd }}$ edn. New Jersey: PrenticeHall International.

47. Mohd Asri, A. (1997). Industri Kecil dan Sederhana di Malaysia: Tinjauan Terhadap Pembangunan Program Bantuan, Kuala Lumpur: Fajar Bakti.

48. Montanari, John R., Morgon, Cyril P. and Bracker, Jeffrey (1990). Strategic Management: A Choice Approach, Orlando: The Dryden Press.

49. Mosakowski, Elaine. (1993). A Resource-Based Perspective on the Dynamic Strategy-Performance Relationship: An Empirical Examination of the Focus and Differentiation Strategies in Entrepreneurial Firms. Journal of Management. Vol.19, No.4: 819-839.

50. Nash, M. (1984). Managing Organisational Performance. San Francisco: Jossey-Bass Publishers.

51. Parker, B. \& Helms, M. (1992). "Generic Strategy and Firms Performance in Declining Industry". Management International Review. Vol. 32, 1, 23-39.

52. Parnell, J. A., \& Wright, P. (1993). "Generic Strategy and Performance: an Empirical Test of the Miles and Snow Typology". British Journal of Management. Vol. 4, 29-36.

53. Porter, M. E. (1980). Competitive Strateg. New york: The Free Press.

54. Porter, M. E. (1985). Competitive Advantage: Creating and Sustaining Superior Performance. New york: The Free Press.

55. Prahalad, C.K. and Hamel, Gary (1990). The Core Competence of the Corporation. Harvard Business Review. May-June: 79-91.

56. Prescott, John E. (1986). Environments as Moderators of the Relationship Between Strategy and Performance. Academy of Management Journal. Vol.29, No.2: 329-346.

57. Price, Robert M. (1996). Technology and Strategic Advantage. California Management Review. 38(3), 3856.

58. Quinn, James Brian (1980). Strategies for Change: Logical Incrementalism, Illinois Richard D. Irwin Inc..

59. Robinson, Richard B. Jr. (1982). The Importance of "Outsiders" in Small Firm Strategic Planning. Academy of Management Journal. 25(1): 80-93.

60. Rothwell, R. (1994). Industrial Innovation; success, strategy, trends, in Dodgson, M. and Rothwell R. (Eds), The Handbook of Industrial Innovation, Edward Elgar, Cheltenham.

61. Rothwell, R. and Zegveld, W. (1985). Reindustrialisation and Technology, Harlow: Longman.

62. Rothwell, William J. and Kazanas, H.C. (1989). Strategic Human Resource Development, New Jersey: Prentice-Hall.

63. Salleh, M.I. (1990). Small and Medium Scale Industrialisation: Problems and Prospects, Kuala Lumpur: Institute of Strategic and International Studies (ISIS).

64. Sankar, Y. (1991). Implementing Information Technology: A Managerial Audit for Planning Change, Journal of Systems Management, 42(11): 32-37.

65. Selznick, P. (1957). Leadership in Administration, New York: Harper and Raw.

66. Sulaiman, M. and Hashim, M.K. (2003). Revisting the Issues and Research Agenda for SMEs in Malaysia, Management School, University Science Malaysia, website: www.management.usm.my/ms.

67. Tarsiah, H.T.. (2007). The Critical Success Factors: A Study On The Small and Medium-Sized Manufacturing Companies In East Malaysia, published PhD Dissertation. University Malaysia Sabah.

68. Teece, D.J. and Pisano, G. (1994). The Dynamic Capabilities of Firms: An Introduction, Industrial and Corporate Change, 3(3): 537-556.

69. Thomas, Aisya S., Litschert, Robert J., and Ramasamy, Kannan. (1991). The Performance Impact of Strategy-Manager Coalignment: An Empirical Examination. Strategic Management Journal. Vol. 12: 509522.

70. United Nations. (1986). Policies and Strategies for Small and Medium Industry Development in Asia and Pacific Region (Mac); Kuala Lumpur.

71. United Nations. (1993). Small and Medium-sized Transnational Corporations, New York: United Nations.

72. Urabe, K. (1988). Innovation and the Japanese Management System, Innovation and Management: International Comparisons, de Gruyter, New York, 3-25.

73. Wheelen, Thomas L. and Hunger, David J. (1995). Strategic Management and Business Policy. Massachusetts: Addison-Wesley Publishing Company. 
74. World Bank (1984), Malaysia: Development Issues and Prospects of Small Enterprises, Report No.3851MA (June).

75. Wren, Daniel A. (1994). The Evolution of Management Thought, $2^{\text {nd }}$ edn. New York: John Wiley and Sons.

76. Zajac, E. J., Golden, B.R. and Shortell, S.M. (1991), New Organizational Forms for Enhancing Innovation: The Case of Internal Corporate Joint Ventures, Management Science, 37(2): 170- 184.

\section{NOTES}




\section{NOTES}

